\title{
My humble opinion on the practice of medical workers of Party members' initial mission in the battle against COVID-19
}

\author{
Bingyang Yao
}

\author{
School of Marxism, Northwestern Polytechnical University, Xi'an Shaanxi 710129, China \\ Email:8767956@qq.com
}

\begin{abstract} prevention and treatment. mission, practice.

\section{STAY TRUE TO YOUR ORIGINAL ASPIRATION, KEEP YOUR MISSION IN MIND, AND RESOLUTELY REFRAIN FROM BUREAUCRATIC FORMALITIES IN THE FIGHT AGAINST THE EPIDEMIC}

Medical workers of Party members is the identity of the doctor and the Marxist believers. In the battle against COVID-19, medical workers of Party members give full play to the leading role of vanguard and model, responding to the call at the first time, going in an opposite direction for the first time, participating in treatment for the first time. They have not only fulfilled the duties of a doctor, but also fulfilled the original mission of a Communist. Medical workers of Party members carry out their original missions, including: sticking to the original mission, keeping the mission in mind, and striving to avoid formalism and bureaucracy in the fight against the epidemics. They stick to the original intention and keep the mission in mind to ensure the safety and health of the people. They carry forward the fighting spirit of the Chinese Communists by carrying forward their original intention and undertaking their mission. Without fear of sacrifice, they overcome difficulties to practice the original mission of the Communists in the practice of epidemic

Keywords: members of the Communist Party doing medical works, epidemic prevention and control, original

In the battle against COVID-19, leading cadres in the medical system have taken on multiple roles. They are not only members of the medical staff, but also front-line commanders guiding the fight against COVID-19. They need to fight side by side with general health care workers, while showing strong leadership in guiding the entire process of epidemic control and treatment. Leading cadres in the medical system should not only lead the medical team to win the battle against the epidemic, but also take practical actions to fulfill their original mission as party members. Therefore, whether the battle without smoke of war can be won, can be fought well, and can be fought beautifully, depends on whether the ideal and belief of leading cadres at all posts is firm, whether the ideological style is good, and whether the working ability is excellent. Leading cadres in the medical system, especially the grassroots cadres, devote themselves to the epidemic prevention and control in the first line. Firmly opposing to and strictly avoiding the phenomenon such as formalism and bureaucracy, leading cadres should "enhance the sense of the victory, responsibility, kindheartedness, prudence, and sharpen the courage of responsibility, the wisdom of scientific prevention and control, the overall consideration of a plan, the ability of organization and implementation, to be responsible for and proper in guarding the land. "[1] Therefore, leading cadres in the medical system should stick to their original intention and keep their mission in mind, avoid formalism and bureaucracy in the fight against the epidemic, and strive to do the following:

First, we should take the initiative to get to know the real situation on the front lines of the epidemic and refuse to be "ignorant" cadres. In the prevention and control of COVID-19 and the treatment of patients, the leading medical officials should take the initiative, implementing their original intention and mission in the prevention and controlling of COVID-19, and go deep into the front line to command operations. In order to keep abreast of the real-time developments of the epidemic, including the effectiveness of epidemic prevention and control, the progress of treatment of patients, and the storage of medical supplies, we must keep a firm and careful track. Leading medical cadres should make arrangements, coordinate and implement them in person, and resolutely put an end to formalism and bureaucracy such as "remote command". Moreover, serious derelict problems such as unclear situation, unclear data and unclear tasks should not occur. Second, we should seek truth from facts, implement the decisions and plans of the Central committee, and refuse to be cadres with "slogans". In the battle against COVID-19, leading medical cadres should obey the Party's command and fully adhere to its leadership. They should neither carry out selective implementation with "policies from above and countermeasures from below", nor shout 
slogans and treat the decisions of higher authorities with mere formalities. Leading cadres should be unified in their knowledge and conduct in epidemic prevention and control, which is the basic party spirit cultivation of Communist Party members. If they fail to do so, they will delay the critical opportunity of epidemic prevention and control due to formalism and bureaucracy. Therefore, the determination of leading medical officials to win the battle against COVID-19 is by no means limited to the mobilization of the numerous materials and meetings, nor is it just a matter of words or appearances. Instead, they should seek truth from facts in the command of COVID-19 prevention and control, and have some achievement in the specific practical action of epidemic prevention. Third, we should assess the situation, grasp the overall situation of epidemic prevention and control, and refuse to be a "happy cadre". Medical cadres need to master the epidemic situation development trend in time, and formulate corresponding strategies according to different situation of development, therefore, leading cadres are required to avoid work negligence and liability accident caused by blind optimism. We should strengthen the "Four Consciousnesss" when controlling epidemic situation, and scientifically recognize epidemic development and evaluation. We must enhance the heart of the prudence, have the bottom line thinking about the risk factors, get the bottom of the problem, and never relax, never be careless until the final victory,"[2] when treating the overall situation

\section{STAY TRUE TO YOUR ORIGINAL INTENTION AND FULFILL YOUR MISSION TO ENSURE THE SAFETY AND HEALTH OF THE PEOPLE}

In the ranks of medical workers, there are many medical workers who are both a doctor and a member of the Communist Party of China. Needless to say, in the face of major public health emergencies, the value targets of doctors and Chinese Communists are consistent and unified, which clearly demonstrates the consistency and unity of Marxist belief and Nightingale's spirit in value concepts. On the one hand, the benevolence of doctors and the original aspiration of Communists to the people are consistent and unified. The benevolence of the doctor is that no matter who the patient is, he or she will try their best to cure him or her. What he or she emphasizes is the compassion, responsibility and justice towards every life. This is consistent and unified with the communist party members' insistence on people-centered values regardless of class division. On the other hand, the mission of healing the wounded and rescuing the dying is consistent and unified with the mission of putting the people's safety and physical health first. It is the logic of doctors' responsibility ethics and responsibility mission to save the dying and heal the wounded, and as a member of the Communist Party, to protect people's lives and safety is obligatory political mission. The consistency and unity of protected objects is obviously the unity of political mission, ethical mission and professional mission.

Being loyal to the original heart and fulfilling the mission is not only the professional requirement of every medical worker, but also the political requirement of every party worker. This smokeless battlefield is a test of the health care worker's original mission. Medical workers, especially those who are party members, are actively at the forefront of treating patients, demonstrating the vanguard and exemplary role of party members and fully embodying the CPC members' sense of purpose of doing everything all for the people and for all the people. In order to win the battle against the epidemic, medical workers put aside their personal difficulties and worked day and night at their posts. In the fight against the epidemic, they have no fear of sacrifice or difficulties in order to increase the admission rate and cure rate and effectively reduce the infection rate and mortality. With their selfless and fearless persistence, they supported a sunny day for the life and health of the people. They adhered to the people-centered approach, and in the war against COVID-19, they performed their duty to keep the soil in place. This dedication is respected both as a healer and as a Party member. During the anti-epidemic period, health care workers were faced with great work pressure and intensity and mental pressure, and their physical load reached the limit. Many medical workers have left bloodstains on their faces because of wearing goggles and masks for a long time; In order to race against time and race against the clock to treat patients, some medical staff simply put on diapers to fight in the operating table...These loveliest people are the brave soldiers who protect the people's life and health. They are the pride of the Party, the country and the people!

\section{CARRY FORWARD THE SPIRIT OF STRUGGLE OF CHINESE COMMUNISTS BY CARRYING FORWARD THEIT ORIGINAL INTENTION AND UNDERTAKING THEIR MISSION}

To carry forward the fighting spirit of Chinese Communists requires the medical workers to practice the original heart of Party members so as to form a tenacious will to fight. The premise of daring to fight and being good at it is to have a tenacious will to fight. Only when the will is firm, can we form the powerful subjective and active role needed in the struggle. At the time of the COVID-19 outbreak, medical workers from all over the country rushed to join the fight against the virus. The reason for the formation of such a sense of dedication, is not only attributed to the responsibility of a doctor, but more importantly to a Communist party member's adherence to ideals and beliefs and the practice of the Party's initial intention. In addition, on the front lines of the fight against the epidemic, there were also a lot of medical workers in a stage of development of Party members who had fully demonstrated the courage to fight in the period of 
development that only a full party members should have, and in the fight against the epidemic, they tempered their initial heart and sharpened their will to fight, which completely represented the sincere heart of these medical workers to get close to the Party organization. Therefore, General Secretary Xi Jinping gave instructions that "active applicants who have shown outstanding performance on the front lines of struggle can be admitted to the Party through the fire line.[5] To be sure, choosing to be close to the Party organization in the most difficult period for the Party, the country and the people is not for any name or selfish gain. They have chosen responsibility, liability and struggle, and they have chosen lofty ideals and beliefs, which are the spiritual realm of the Communist Party members. It is in the practice of fighting against the epidemic that every medical worker has honed his or her own will to fight, thus forming the fighting spirit of the Communist Party members. Therefore, it is not enough to shout slogans, but to be reflected in the moment when the Party, the country and the people need it most.

To carry forward the fighting spirit of Chinese Communists, medical workers of Party members are also required to take the initiative to undertake their missions, so as to acquire excellent fighting skills. The responsibility and mission of medical workers of Party members are different from that of ordinary medical workers. The responsibility and mission emphasized by medical workers of Party members will far exceed that of ordinary medical workers. They are not only confined to the identity of a doctor to meet the professional requirements of life-saving, but more important to fight against the virus on this basis, and fight against the epidemic. The fight against the epidemic fully demonstrates the communist Party members' governance ability in the face of major public health emergencies, and is also a practical test of their fighting ability. The spirit of struggle of Communists is by no means merely an empty talk, but must be embodied in concrete practice. The need to constantly enhance their ability to fight from the practice of struggle to the awareness of struggle, and then to the practice of struggle, and so on. Sharp sword comes from the sharpening out, and plum blossom incense comes from the cold weather. Medical workers who have experienced the war against COVID-19 have tempered their will, improved their ability and enhanced their skills in the struggle and practice. Proceeding from the progress of epidemic prevention and control, they have discovered patterns, summarized the experience and found the method in the struggle, which has effectively contained the spread and development of the epidemic.

\section{CONCLUSION}

The struggle was cruel, but it was also great. Under the leadership of the Party, Party members' of medical workers are brave and good at fighting in the practice of their original mission, which has strengthened the Party's organizational foundation and strength, and won the people's war against COVID-19 in stages together with other anti-epidemic fighters. They are the loveliest people, but also the worthiest of respect, they are not only angels in white, but also the embodiment of the people's heroes.

\section{References}

[1] Xi Jinping. Remarks on COVID-19 prevention and control work in Hubei Province [J]. Struggle, No.7, 2020, P:4-11.

[2] Xi Jinping. Speech at the Meeting on COVID-19 Prevention and Control and Deployment of Economic and Social Development [M]. Beijing: People's Publishing House, 2020, P:25.

[3] [4] Xi Jinping $\mathrm{Xi}$ Jinping talks on governance. Volume 3 [M]. Beijing: People's Publishing House, 2020, P:137,226.

[5] Excerpt and compilation of Xi Jinping's Important Treatise on Fighting against Formalist Bureaucracy [M]. Beijing: Central Documents Publishing House, 2020, P117. 